\title{
Tenofovir (TDF) containing first-line HAART is associated with changes in plasma parameters suggestive of increased bone resorption
}

\author{
Pablo Labarga*, Pablo Barreio, Carlos A Sanchez, Jose Medrano, Eugenia Vispo, Jose Vicente Fernandez, \\ Francisco Blanco, Juan Gonzalez-Lahoz, Vicente Soriano
}

From $16^{\text {th }}$ International Symposium on HIV and Emerging Infectious Diseases Marseille, France. 24-26 March 2010

\section{Background}

Prolonged treatment with tenofovir (TDF) containing HAART is associated with reductions in kidney tubular resorption of phosphorus (P). Added to this, TDF may directly affect bone remodeling. Current study analyses the potential repercussion of Calcium $(\mathrm{Ca})$ and $\mathrm{P}$ wasting on bone-mineral metabolism.

\section{Methods}

All consecutive asymptomatic HIV-infected patients starting first-line HAART were recruited. Patients receiving HARRT with vs without TDF were considered separately. Changes with respect to baseline values in $\mathrm{Ca}$ and $\mathrm{P}$ plasma levels, alkaline phosphatase (AP) concentration and parathyroid hormone (PTH) levels were analyzed in patients followed for longer than 12 months. Adherence $>95 \%$ as assessed every 4 months was requested to remain in the study.

\section{Results}

A total of101 patients were included, 64 (63\%) received TDF and 37 (37\%) non-TDF containing HAART (mean age 38 years-old, $92 \%$ males, $90 \%$ Caucasians, mean CD4 count 278 cells/uL, mean HIV-RNA $4.3 \log$ copies $/ \mathrm{mL}$, without differences between groups). After a mean follow up of 18 months, mean variation in bone-mineral metabolism plasma parameters with respect to baseline values, in patients under TDF vs non-TDF, was respectively as follows: P levels $-0.31 \mathrm{mgr} / \mathrm{dL}$ [p $<0.001]$ vs $-0.05 \mathrm{mg} / \mathrm{dL}$ $[\mathrm{p}=0.7]$; Ca levels $+0.24 \mathrm{mg} / \mathrm{dL}[\mathrm{p}=0.005] \mathrm{vs}+0.23 \mathrm{mg} /$ $\mathrm{dL}[\mathrm{p}=0.36]$; AP concentration $+60 \mathrm{IU} / \mathrm{L}[\mathrm{p}=0.005] \mathrm{vs}$

\footnotetext{
* Correspondence: pablolabarga@gmail.com Hospital Carlos III, Madrid, Spain
}

$-36 \mathrm{IU} / \mathrm{L}[\mathrm{p}=0.09]$; and PTH levels $+20.3 \mathrm{pgr} / \mathrm{mL}$ $[\mathrm{p}=0.02] \mathrm{vs}+12.6 \mathrm{pgr} / \mathrm{mL}[\mathrm{p}=0.25]$.

\section{Discussion}

First-line HAART containing TDF, as compared with other nucleoside analogs, is associated with significant reductions in P levels, and increase in AP and PTH concentrations. These alterations are recognized markers of enhanced bone resorption, and may herald osteopenia in the long-term.

Published: 11 May 2010

doi:10.1186/1742-4690-7-S1-013

Cite this article as: Labarga et al:: Tenofovir (TDF) containing first-line HAART is associated with changes in plasma parameters suggestive of increased bone resorption. Retrovirology 2010 7(Suppl 1):013.
Submit your next manuscript to BioMed Central and take full advantage of:

- Convenient online submission

- Thorough peer review

- No space constraints or color figure charges

- Immediate publication on acceptance

- Inclusion in PubMed, CAS, Scopus and Google Scholar

- Research which is freely available for redistribution

Submit your manuscript at www.biomedcentral.com/submit
Biomed Central 